\title{
Biochar from Waste Derived Fuels as Low-Cost Adsorbent for Waste Hydrocarbons
}

\author{
Dmitrijs PORSNOVS ${ }^{1 *}$, Linda ANSONE-BERTINA², Jorens KVIESIS ${ }^{3}$, Dace ĀRIN̦A ${ }^{4}$, \\ Maris KLAVINS 5 \\ ${ }^{1-3,5}$ Department of Environmental Sciences, University of Latvia, Jelgavas st. 1, Riga, Latvia \\ ${ }^{4}$ Institute of Physical Energetics of Latvia, 11 Krīvu Street, LV-1006, Riga, Latvia
}

\begin{abstract}
The aim of this study is to prove technical feasibility of combined refuse derived fuel (RDF) torrefaction and oily wastewater treatment approach by using RDF derived biochar as a sorption media. Biochars prepared from refuse derived fuels in torrefaction, carbonization and pyrolysis modes were analysed as fuels and as hydrocarbon sorbents. Changes of elemental composition and properties of material during thermal treatment and subsequent washing process have been analysed. Experimental evaluation of sorption behaviour of toluene and diesel fuel on obtained biochar performed. Our results show that torrefaction/carbonization of RDF coupled with the subsequent washing of biochar is a method allowing to overcome absolute majority of the quality problems of waste derived fuels, including the most important one: high chlorine content. In spite the fact that optimal temperatures for upgrading waste derived fuels and to produce high quality sorbent does not coincide, technically it is possible to combine the washing of torrefied/carbonized waste derived fuels with the treatment of wastewaters that are polluted with oils or hydrocarbons.
\end{abstract}

Keywords - Absorption; carbonization; emulsified wastes; RDF (Refuse derived fuel); torrefaction

\begin{tabular}{|lll}
\hline Nomenclature & & \\
$m$ & Mass & $\mathrm{kg}$ \\
$H H V$ & Higher heating value & $\mathrm{MJ} / \mathrm{kg}$ \\
$\Delta m_{t o t}$ & Total extracted amount & $\mathrm{g}$ \\
$C$ & Concentration of substance & $\mathrm{mg} / \mathrm{g}$ \\
$V$ & Volume & $\mathrm{ml}$ \\
$Q$ & Sorption capacity & $\mathrm{g} / \mathrm{g}$ \\
$W$ & Mass of sorbent & $\mathrm{g}$ \\
$q$ & Absorbed amount of substance & $\mathrm{g}$ \\
$t$ & Time & $\mathrm{min}$ \\
$k_{1}$ & Reaction rate constant & $1 / \mathrm{min}$
\end{tabular}

* Corresponding author.

E-mail address: dmitrijs.porsnovs@lu.lv 


\section{INTRODUCTION}

Generation of solid organic wastes is one of the greatest challenges of today. By 2025 worldwide production of municipal solid wastes can reach approximately 2.2 billion tons per year, of which in average $46 \%$ are formed by biomass, $17 \%$ by paper and $10 \%$ by plastics [1]. Production of waste derived fuels from the organic fraction of unrecyclable post-consumer waste is widely accepted and have showed the ability to help us to "close the loop" in the whole waste recovery mind-set [2]. While in the same time, waste derived fuels usually are of very low quality due to high moisture content, low energetic value, high heterogeneity, presence of unwanted elements and complex structure, preventing effective grinding of this material [3], [4]. In this respect as prospective can be considered carbonization and torrefaction of the organic part of municipal solid waste. Recent studies have showed that pyrolytic pre-treatment such as torrefaction or carbonization is able to upgrade properties of waste derived fuels significantly [5]-[8]. Usually torrefaction is defined as a slow heating of biomass or waste derived feedstock in an inert environment and temperature range of $200-300{ }^{\circ} \mathrm{C}$ [9]-[11]. The fundamental principle of torrefaction is preferential and selective degradation of lower calorific fraction present in the feedstock [12]. Furthermore, as it is pointed in [13], 90 \% of chlorine contained in PVC may be removed by torrefaction at $260-300{ }^{\circ} \mathrm{C}$ due to transformation of mentioned substance from the organic form into hydrochloric acid and its subsequent evaporation.

The study [8] have showed, that thermal treatment of waste derived fuels itself is not able to deal with high chlorine content, while excessive chlorine may be removed using water leaching after the pyrolysis. It is clear, that the use of clean water in leaching process is unwanted from economic as well as from environmental point of view as it is resulting in high volumes of wastewaters.

Liquid wastes consisting of water and hydrocarbons and/or oils as well must be viewed as serious environmental problem of today, large amount of such wastes is generated on daily basis from various industries [14]. Such waste emulsions may cause technical problems in wastewater treatment plants as well as to have a negative influence on the quality of the wastewater treatment plant effluent. Therefore, oil content reducing measures must be taken before release of such by-product into municipal waste treatment units or the environment [15]. Conventional gravitational techniques like gravity settling, centrifuges, and air flotation, are not effective enough for the separation of oil-in-water emulsions [14]. Recently multiple modern methods of de-emulsification such as the use of magnetic particles as the demulsifying agent [16], filtration membranes made from polymers with specific wetting properties (simultaneous hydrophobicity/oleophilicity) [17], [18] while in spite to the technical complexity of these methods all of them expresses similar drawback: they fit into linear 'take-make-dispose' approach. Today linearity must be viewed as obsolete concept: the aim of XXI century is to close the loop and to redefine refuse as resource [19]. Adsorption and coalescence filtration are promising choice of treatment of oily wastewaters for its simplicity, effectiveness and feasibility when appropriate sorbent is used [20]. Bio-chars obtained as a result of thermochemical processes have showed good sorption properties, exceeding the quality of industrial products by certain indicators [21].

The aim of this study is to prove technical feasibility of combined RDF torrefaction and oily wastewater treatment approach by using RDF torrefaction/carbonization biochar as a sorption media. 


\section{MATERIALS AND METHODS}

\subsection{Torrefaction / Carbonization}

Samples of RDF were collected in 5 waste processing facilities in Latvia and Estonia, the names of facilities are not disclosed; technical methods used in preparation of studied RDFs are showed in Table 1. Collection of samples performed after the shredder (or after bio treatment in some cases). In every factory, 20 samples (around $1 \mathrm{~kg}$ each) were taken and then mixed. The dominant fraction in all samples was the plastic fraction, fractional composition of samples is demonstrated in Fig. 1. Samples were shredded to particle size $<1 \mathrm{~mm}$ to reduce an error caused by the inhomogeneity of material. Thermal treatment performed in closed steel cylinders filled with nitrogen, in laboratory oven, at 200, 300, 400 and $500{ }^{\circ} \mathrm{C}$. The mass of the sample in the reactor was $50 \mathrm{~g}$. The heating rate was $20{ }^{\circ} \mathrm{C} / \mathrm{min}$, the heating time (sum of heating up and holding times) was 3 hours in all cases. Natural cooling down was applied after the treatment.

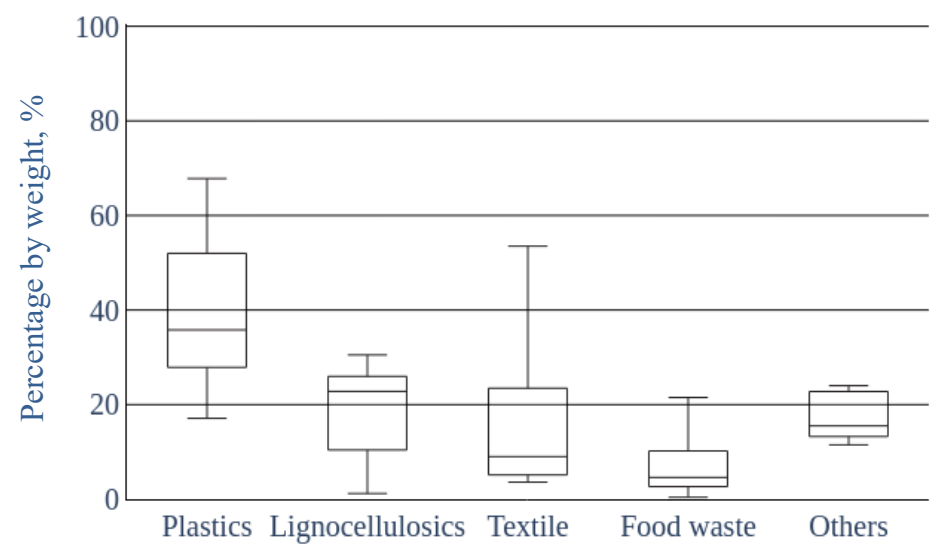

Fig. 1. Composition of used RDFs.

\subsection{Characterization of biochar}

Calorific value was determined according to standard method [22] by using bomb calorimeter Berthelot Mahler, I.S.Co at constant volume.

Nitrogen, carbon and hydrogen content determined according to standard method [23] using a Thermo Fisher Scientific Flash EA1112 Series analyser. Five measurements per sample are carried out. The tin capsule with sample is inserted into the combustion reactor, where the sample is combusted in the presence of oxygen and catalyst. After the combustion reaction, the gaseous products $\left(\mathrm{CO}_{2}, \mathrm{H}_{2} \mathrm{O}, \mathrm{NO}_{\mathrm{x}}\right)$ are transferred by a helium flow through the copper. Copper reduces nitrogen oxides to nitrogen and removes excess oxygen $(\mathrm{CuO})$. The gases then flow through a column where the gases are separated and detected. As a result, the hardware program outputs the percentage composition of the elements. The elemental composition is determined by comparing the sample with a standard substance (acetanilide $\mathrm{C}_{8} \mathrm{H}_{9} \mathrm{NO}$ ) and a reference factor called $\mathrm{K}$-factor. Oxygen content calculated considering results of described measurement and ash content. 
Sulphur and chlorine content determined according to standard method [24], by digestion in calorimetric bomb (Berthelot Mahler, I.S. Co) and photometric detection by a Pharol00 Spectroquant.

Proximate analysis was made using thermogravimetric method described in [25], in 5 replicates, results averaged.

Mass yields calculated using the Eq. (1).

$$
M_{\text {yield }}(\%)=\frac{m_{\text {char }}}{m_{R D F}} \cdot 100
$$

TABle 1. TeChNOlogical ApProaches Used for the PREPARATION OF ANALYSED RDFs

\begin{tabular}{cl}
\hline Sample & \multicolumn{1}{c}{ Description } \\
\hline RDF 1 & $\begin{array}{l}\text { Mixed municipal waste is screened, metals separated. Then leftovers are sorted by means of manual } \\
\text { sorting and air stream, then fine shredded. }\end{array}$ \\
\hline RDF 2 & $\begin{array}{l}\text { Mixed municipal waste is shredded (200-400 mm), metals separated. Then waste is screened on } \\
\text { vibrating screen and in trommel drum. Light fraction is separated by air stream, then fine shredded. }\end{array}$ \\
\hline RDF 3 & $\begin{array}{l}\text { Mixed municipal waste is shredded, metals separated, then leftovers screened using trommel drum. } \\
\text { Coarse fraction is sorted manually and by means of air stream. Then fine shredded. }\end{array}$ \\
\hline RDF 4 & $\begin{array}{l}\text { Mixed municipal waste is shredded and screened } 60 \text { mm. Then fine shredded. No biotreatment } \\
\text { performed. }\end{array}$ \\
\hline RDF 5 & $\begin{array}{l}\text { Mixed material waste is shredded and stored in naturally ventilated large heaps for few months. Then } \\
\text { screened (40 mm) and fine shredded. }\end{array}$ \\
\hline
\end{tabular}

Energy yields calculated using the Eq. (2).

$$
E_{\text {yield }}(\%)=M_{\text {yield }} \cdot \frac{H H V_{\text {char }}}{H H V_{R D F}} \cdot 100
$$

Sample surface was analysed by Brunauer-Emmett-Teller (BET) method [26], using a Quadrasorb SI gas sorption analysis system (Quantachrome Instrumentis, Boynton Beach, USA). Liquid nitrogen (at $-196^{\circ} \mathrm{C}$ ) was applied for the physical sorption-desorption isotherms.

\subsection{Washing of Biochar}

Samples of RDFs torrefied $\left(300^{\circ} \mathrm{C}\right)$ as described before were used. Around $2.5 \mathrm{~g}$ of samples have been weighed in a cellulose capsule and sealed with glass fiber. Afterwards the capsules were placed in a Soxhlet extraction unit (Behr Labor-Technik), distilled water was used as a solvent, and the procedure was applied for $8 \mathrm{~h}$. After extraction the water was collected, its volume $(V)$ measured. The capsules were dried and weighed, the total extracted amount $\left(\Delta m_{t o t}\right)$ was calculated. Concentrations (C) of 25 different elements (Al, As, B, Ba, Be, Ca, $\mathrm{Cd}, \mathrm{Co}, \mathrm{Cr}, \mathrm{Cu}, \mathrm{Fe}, \mathrm{K}, \mathrm{Mg}, \mathrm{Mn}, \mathrm{Mo}, \mathrm{Na}, \mathrm{Ni}, \mathrm{P}, \mathrm{Pb}, \mathrm{S}, \mathrm{Si}, \mathrm{Sr}, \mathrm{V}, \mathrm{Zn}$ ) were quantified in water phase by using ICP-OES (Thermo Scientific iCAP 7000 series).

Sulphate ion $\left(\mathrm{SO}_{4}{ }^{2-}\right)$ determined as follows: $25 \mathrm{~mL}$ of filtered sample was added to an Erlenmeyer flask, $2.5 \mathrm{~mL}$ of conditioning reagent was added, as well as a pinch of $\mathrm{BaCl}_{2}$. The solution was mixed and after 5 minutes was measured on a spectrophotometer (Hach-Lange DR2800) at $450 \mathrm{~nm}$ wavelength (Hach ${ }^{\circledR}$ method 680). Distilled water was used as a blank. Concentration $(\mathrm{C})$ determined according to the calibration curve. 
Bicarbonate $\left(\mathrm{HCO}^{3-}\right)$ determined as follows: $50 \mathrm{~mL}$ of sample was transferred to a $250 \mathrm{~mL}$ flask and 5 drops of methyl orange indicator was added. The sample was titrated with $0.1 \mathrm{~N} \mathrm{HCl}$. Experiments were run in triplicate. Results were calculated after titration results.

Chloride ions $\left(\mathrm{Cl}^{-}\right)$determined as follows: $50 \mathrm{~mL}$ of sample was transferred to a $250 \mathrm{~mL}$ flask and $1 \mathrm{~mL}$ of $10 \% \mathrm{~K}_{2} \mathrm{CrO}_{4}$ solution was added. The sample was titrated with $0.02 \mathrm{~N}$ $\mathrm{AgNO}_{3}$. Experiments were run in triplicate. Results were calculated from titration results.

The amount of insoluble $\mathrm{CaCO}_{3}$ formed in the water phase during the process estimated by using gravimetric method.

The percentage of every substance in total dissolved substance calculated by using the Eq. (3).

$$
w(\%)=100-\left[\frac{\Delta m_{t o t}-\frac{c}{1 / V}}{\Delta m_{t o t}} \cdot 100\right]
$$

\subsection{Toluene Adsorption Study}

Headspace Gas Chromatography (HS-GC). A TurboMatrix 40 Trap automatic HS injection system coupled with the Clarus 580 GC unit equipped with a flame ionization detector (FID) was used. The injection port of the GC system was operated at $220^{\circ} \mathrm{C}$, split less mode, and 35 psi of pressure. A flame ionization detector was employed with hydrogen and air flow rates of 45 and $450 \mathrm{~mL} / \mathrm{min}$, respectively. Helium at $20 \mathrm{~cm} / \mathrm{s}$ linear velocity was the carrier gas. The detector temperature was set at $250{ }^{\circ} \mathrm{C}$. The headspace operating conditions were as follows: 5 min shaking for the sample equilibration at a temperature of $75^{\circ} \mathrm{C}$; needle temperature of $180^{\circ} \mathrm{C}$; vial pressurization time of $0.5 \mathrm{~min}$; vial pressure of $40 \mathrm{psi}$; sample loop filling time of $1.6 \mathrm{~min}$, trap low and high temperature $50{ }^{\circ} \mathrm{C}, 290{ }^{\circ} \mathrm{C}$; trap hold time $5.0 \mathrm{~min}$; desorb time, 0.5 ; desorb pressure, $35 \mathrm{psi}$; transfer line temperature of $180{ }^{\circ} \mathrm{C}$; dry purge time, $0.5 \mathrm{~min}$; and GC cycle time $24.8 \mathrm{~min}$.

GC separation was carried out on a SPB-624 Capillary Column $(60 \mathrm{~m} \times 0.25 \mathrm{~mm} \times 1.4 \mu \mathrm{m}$; Supelco). Toluene was determined by the temperature program of the oven which was initially holding at $60{ }^{\circ} \mathrm{C}$ for 1 minute, increasing by $4.0^{\circ} \mathrm{C} / \mathrm{min}$ to $155^{\circ} \mathrm{C}$.

The produced powdered bio-char samples $(250 \mathrm{mg})$ were thoroughly mixed with of $5.0 \mathrm{ml}$ deionized water hermetically sealed in a $21.6 \mathrm{~mL}$ glass bottle with toluene to obtain solution at approximately $877-43831 \mathrm{mg} / \mathrm{L}$ concentration (toluene solubility $535 \mathrm{mg} / \mathrm{L}$ ). The resulting solution was stirred 6 and 24 hours in the shaker by room temperature. The solution was then filtered on a membrane filter $(0.45 \mu \mathrm{m})$ in no permeable vial $(21.6 \mathrm{~mL})$ and $3.0 \mathrm{ml}$ by volume filtrate directly submitted to HS-GC analysis.

\subsection{Diesel Adsorption Study}

The sorption study was carried out in a batch system at room temperature. Using stainless steel net $0.1 \mathrm{~g}$ of sorbent was immersed into the glass beaker, filled with $50 \mathrm{~mL}$ of diesel fuel. After 30 min of sorption the wet sorbent was taken out, then drained for $2 \mathrm{~min}$ in air, and finally dried using filter paper and weighted. The diesel fuel sorption capacity for sorbent were obtained based on following Eq. (4) [27]-[29].

The effect of sorbent dosage on the amount of sorbed diesel fuel was studied by using sorbent mass between $0.05 \mathrm{~g}$ and $2 \mathrm{~g}$. 


$$
Q=\frac{w_{2}-w_{1}}{w_{1}},
$$

where

$Q \quad$ Sorption capacity of diesel fuel, $\mathrm{g} / \mathrm{g}$;

$w_{2} \quad$ Mass of wet sorbent after sorption, $\mathrm{g}$;

$w_{1} \quad$ Mass of the sorbent before sorption, $\mathrm{g}$, each sample was measured 3 times.

Sorption kinetics study of diesel fuel on RDF sorbents. Using stainless steel net $0.1 \mathrm{~g}$ of sorbent was immersed into the glass beaker, filled with $50 \mathrm{~mL}$ of diesel fuel. The sample and net were taken out at different time intervals $(10 \mathrm{~s}, 30 \mathrm{~s}, 1 \mathrm{~min}, 1.5 \mathrm{~min}, 2 \mathrm{~min}, 6 \mathrm{~min}, 15 \mathrm{~min}$, $30 \mathrm{~min}, 1 \mathrm{~h}$ and $24 \mathrm{~h}$ ). The wet material was drained and weighted as previously mentioned.

\section{Results AND Discussion}

\subsection{Characterization of Biochar}

Changes in feedstock composition during the low temperature torrefaction $\left(200^{\circ} \mathrm{C}\right)$ were insignificant, mass lose was only $4 \%$ (Fig. 2), colour of material remained unchanged, no signs of carbonization observed. In spite to the small increase of calorific value (energy yield: $101.2 \%$ ) treatment in low temperature torrefaction regime seems to be senseless for the treatment of refuse derived fuel. In turn, high temperature torrefaction $\left(300{ }^{\circ} \mathrm{C}\right)$ provided significant changes of material, $15 \%$ mass lose and energy yield $93.5 \%$ (Fig. 2.). Slight decrease in volatile matter, carbon and oxygen content as well as increase of fixed carbon and ash levels observed (Table 3). Removal of chlorine that have been observed by [5] during the torrefaction treatment of small RDF samples under conditions of purging nitrogen gas was not observed in our experiment. This fact coincides with the findings of [8] and demonstrates that fixed bed torrefaction is able only to transform organic chlorine into inorganic form but is not able to remove it due to absorption of the formed hydrochloric acid on surrounding material. Thermal treatment of RDF in carbonization $\left(400^{\circ} \mathrm{C}\right)$ regime seems to be excessively aggressive if the only objective is to increase the quality of the solid product. This finding is completely compliant with the results of [30]. This treatment regime results in strong transformation of the fuel and almost complete removal of the plastics: the fraction with the highest energetic value. Therefore, energy yield in this case is too low (Fig. 2) but resulting ash content value is too high (Table 3). Such treatment seems to be useful only if the process is organized in a way able to produce marketable product not only from the resulting solid fraction, but from volatiles as well. Treatment in pyrolysis regime $\left(500{ }^{\circ} \mathrm{C}\right)$ seems to be the only one that is able to increase the surface area of obtained bio-char (Table 3), while in the same the time fuel value of the solid residue in this case is very low (Table 3, Fig. 2).

\subsection{Washing of Biochar}

Results of washing experiment of torrefied RDF have showed that the combination of torrefaction and subsequent washing is much more effective method for the improvement of $\mathrm{RDF}$ quality than torrefaction alone. Washing results in the removal of soluble $\mathrm{Ca}, \mathrm{Na}$ and $\mathrm{K}$ salts (bicarbonates, sulphates and chlorides) from the material, in the same time amounts of other metals in the washed away fraction do not exceed $1 \%$ (Fig. 3). Active formation of the insoluble calcium carbonate containing substance is observed during the washing process. As it is showed in Fig. 4, washing significantly increases the calorific value of torrefied waste derived fuels by reducing its ash content. Furthermore, this process almost completely 
removes chlorine, being the worst quality problem of RDF, inducing severe operational issues, including boiler corrosion and production of problematic emissions such as hydrochloric acid and dioxins during the combustion [31]. Washing also significantly reduces sulphur content, also is responsible for corrosion issues in incineration plants [32].

TABLE 3. COMPOSITION AND PROPERTIES OF INITIAL RDF AND OBTAINED BIOCHARS

\begin{tabular}{|c|c|c|c|c|c|c|c|c|}
\hline & $\mathrm{N}, \%$ & $\mathrm{C}, \%$ & $\mathbf{H}, \%$ & $0, \%$ & $\begin{array}{l}\text { Volatiles, } \\
\%\end{array}$ & $\begin{array}{l}\text { Fixed } \\
\text { carbon, } \\
\%\end{array}$ & Ash, \% & $\begin{array}{l}\text { BET } \\
\text { surface } \\
\text { area, } \\
\mathbf{m}^{2} / \mathbf{g}\end{array}$ \\
\hline $\mathrm{RDF}$ & $1.1 \pm 0.7$ & $56.1 \pm 3$ & $4.4 \pm 0.5$ & $21.4 \pm 7$ & $76.0 \pm 2$ & $5.8 \pm 2$ & $15.8 \pm 2$ & - \\
\hline $\mathrm{RDF} 300^{\circ} \mathrm{C}$ & $1.2 \pm 0.7$ & $50.5 \pm 3$ & $4.3 \pm 0.5$ & $16.8 \pm 7$ & $63.3 \pm 2$ & $11.2 \pm 2$ & $26.4 \pm 2$ & 0.8 \\
\hline $\mathrm{RDF} 400^{\circ} \mathrm{C}$ & $1.1 \pm 0.7$ & $44.3 \pm 3$ & $4.0 \pm 0.5$ & $7.2 \pm 7$ & $38.2 \pm 2$ & $17.8 \pm 2$ & $42.2 \pm 2$ & 0.5 \\
\hline $\operatorname{RDF} 500^{\circ} \mathrm{C}$ & $1.5 \pm 0.7$ & $26.0 \pm 3$ & $3.5 \pm 0.5$ & $9.3 \pm 7$ & $19.8 \pm 2$ & $19.8 \pm 2$ & $58.4 \pm 2$ & 49.6 \\
\hline
\end{tabular}

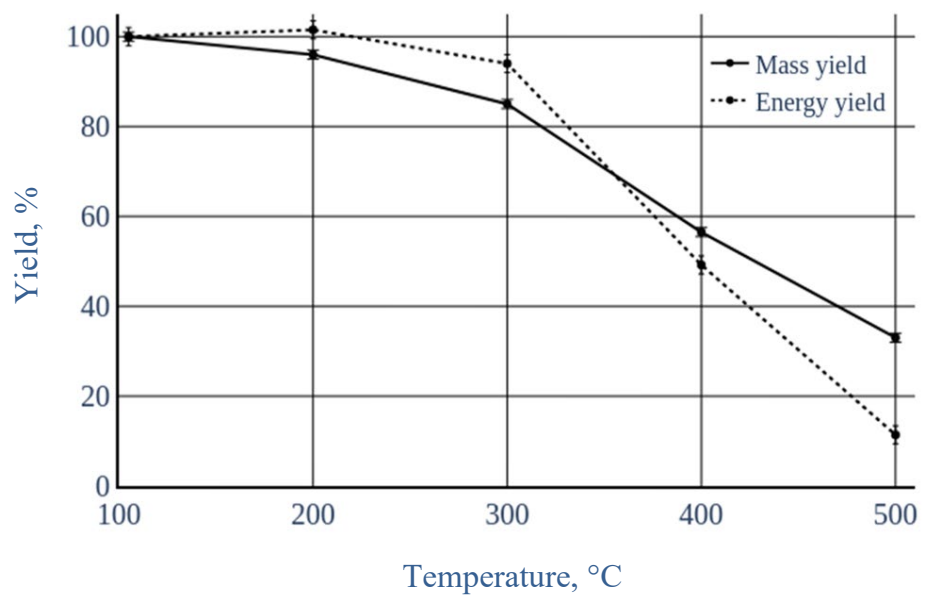

Fig. 2. Mass and energy yields in solid residue as a result of treatment at different temperatures. 


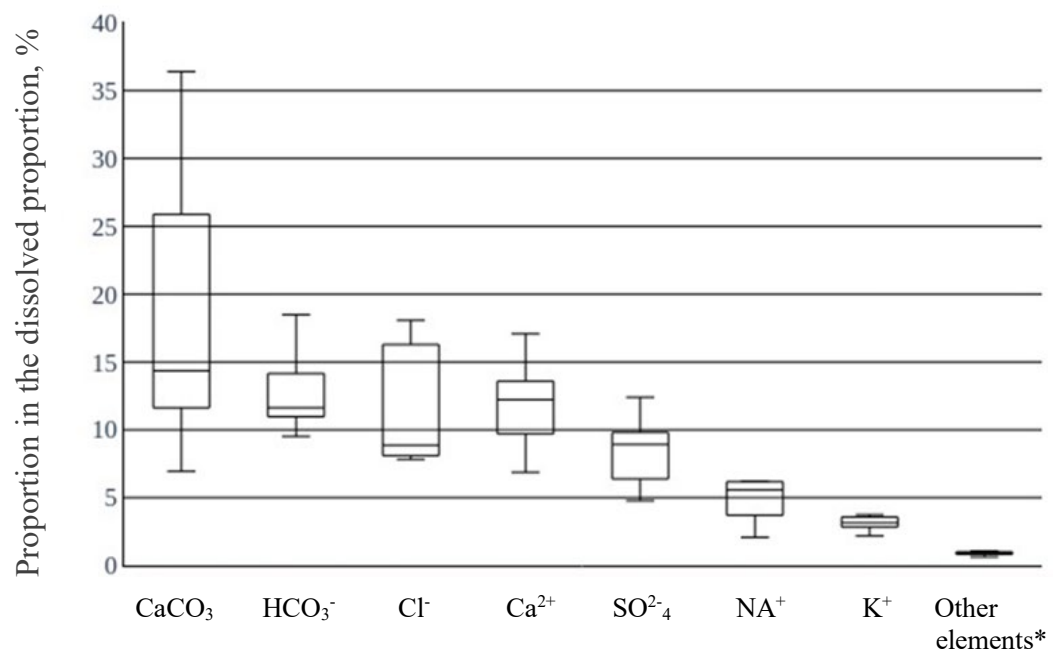

*Al$+\mathrm{As}+\mathrm{B}+\mathrm{Ba}+\mathrm{Cu}+\mathrm{Fe}+\mathrm{Mg}+\mathrm{Mn}+\mathrm{Mo}+\mathrm{Ni}+\mathrm{P}+\mathrm{Pb}$

Fig. 3 Composition of the part of biochar dissolved as a result of washing.

\section{(A) Higher heating value}

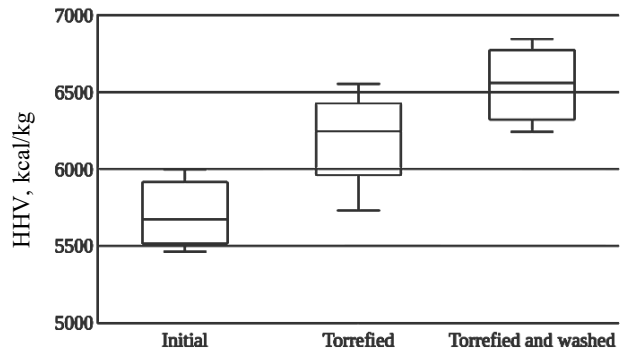

(C) Chlorine content

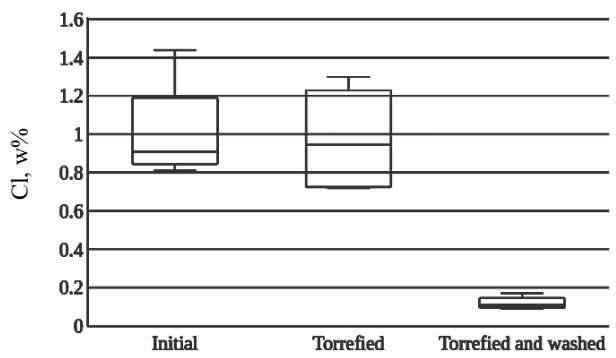

(B) Ash content

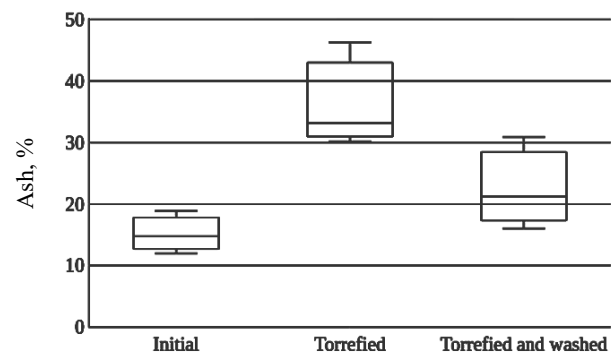

(D) Sulphur content

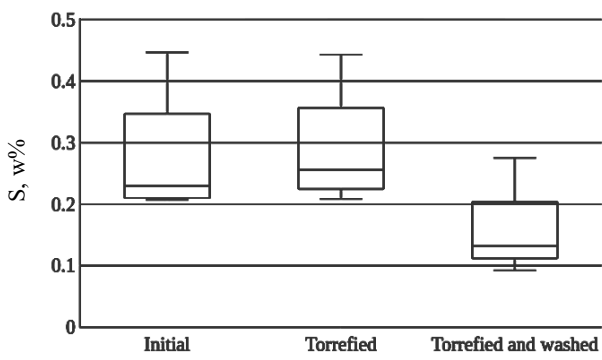

Fig. 4. Changes in composition and properties of RDFs during torrefaction and subsequent washing. 


\subsection{Characterization of Sorption Properties of Biochar}

Toluene sorption were investigated on biochars produced at various temperatures. Fig. 5 . displays the sorption data, experiments were performed at room temperature for $24 \mathrm{~h}$. Obtained results show differences between sorbents that are heated at temperatures from $300{ }^{\circ} \mathrm{C}$ to $500{ }^{\circ} \mathrm{C}$. Although the form of all isotherms is similar, they exhibit a very unfavourable trend, with an almost square convex shape to the concentration axis $(\mathrm{Ce})$. The sorption isotherm representing sorbed amount of toluene onto biochar sorbent heated at $300^{\circ} \mathrm{C}$ is convex to the axis of equilibrium concentration of toluene up to a concentration value about $410 \mathrm{mg} / \mathrm{L}$, very similar to that also isotherm of biochar heated at $400{ }^{\circ} \mathrm{C}$ is convex to axis of equilibrium concentration up to concentration value about $370 \mathrm{mg} / \mathrm{L}$. Different properties are observed for the sample heated at $500{ }^{\circ} \mathrm{C}$ temperature - it has considerably higher surface area in comparison to the samples heated at $300{ }^{\circ} \mathrm{C}$ and $400{ }^{\circ} \mathrm{C}$ temperature and the point of inflexion is shifted towards lower concentration value of toluene and is observed at the value of $320 \mathrm{mg} / \mathrm{L}$. These isotherms show that toluene uptake increases exponentially with increasing concentration. According to [33] the shapes of obtained isotherms fall within type III, and according to [34] classification the isotherms follow S type curve pattern. The initial direction of curvature indicate that adsorption become easier with the rise of sorbate concentration. The more sorbate is absorbed, the easier it is for additional amounts of sorbate to bound to the sorbent; thus, $\mathrm{S}$ curves indicate to side-by-side association between absorbed species, thus ensuring adhesion to the surface of the sorbent. According to [34] curves indicate vertical orientation of adsorbed molecules at the surface, the solute molecule is monofunctional and meets strong competition for sorbent sites, from molecules of solvent or of another adsorbed species.

The sorbed amount of diesel fuel is increasing with increase of sorbent dose from $0.05 \mathrm{~g}$ to $0.5 \mathrm{~g}$ (Fig. 6). The maximum diesel fuel sorption capacity of biochar is $2 \mathrm{~g} / \mathrm{g}$. The initial increasing trend can be explained by the increase in surface area - number of available sorption sites increases by increasing the sorbent dose. Further increase in sorbent dose over $0.5 \mathrm{~g}$ reduced sorption capacity of biochar. The decrease in sorption capacity with increase in sorbent dose could be due to the high number of unsaturated sorption sites. As sorbent weight increases possible is material compacting which may decrease ability of diesel fuel to penetrate the material evenly, as well as sorbent surface aggregation may occur as a result surface area may decrease, diffusional holes may be blocked, and sorption sites may be unsaturated [35]. The results of our study agree with other studies using different materials for diesel fuel removal (Table 4). However, it is worth to mention that experimental conditions like sorbent dosage, initial concentration, $\mathrm{pH}$, ionic strength, sorption time and temperature significantly affect sorption process and consequently also maximal sorption capacity. Sorption kinetics gives valuable insight in the pathway of sorption process and sorption mechanism. The sorption kinetics of diesel fuel on heated biochar samples was studied as a function of time at room temperature. Sorption capacity increases with increasing sorption time until it reaches the maximum of $2.55 \mathrm{~g} / \mathrm{g}$ after $24 \mathrm{~h}$. According to the results of sorption kinetics study (Fig. 7), the rate of diesel sorption is very high at the beginning - most of the diesel fuel are sorbed within first $6 \mathrm{~min}$ (sorbed amount reach $1.9 \mathrm{~g} / \mathrm{g}$ ). After that the rate of the diesel sorption is gradually reduced and become steady. During the first $10 \mathrm{~min}$ sorption capacity increased rapidly which may be due to availability of sorption sites on the surface of the sorbent, but as the surface of the sorbent becomes saturated with molecules of sorbates the sorption rate tends to decrease. Additional experiment was carried out at $24 \mathrm{~h}$ and sorbed amount of diesel fuel slightly increased, reaching $2.55 \mathrm{~g} / \mathrm{g}$. 
TABLE 4. COMPARISON OF DIESEL SORPTION CAPACITIES

\begin{tabular}{llll}
\hline Sorbent & Sorbate & Sorbed amount, g/g & Reference \\
\hline sawdust & diesel & 1.6 & {$[36]$} \\
straw & diesel & 3,9 & {$[36]$} \\
wool & diesel & 5.6 & {$[36]$} \\
moss & diesel & 6.2 & {$[36]$} \\
peat & diesel & 6.3 & {$[36]$} \\
sapropel & diesel & 2.5 & {$[37]$} \\
luffa & diesel & $6-12$ & {$[38]$} \\
peat biochar & crude oil & $5.9-8.6$ & {$[39]$} \\
peat & crude oil & $3.5-6$ & {$[40]$} \\
oil palm leaves & crude oil & 1.18 & {$[41]$} \\
MSW biochar & toluene & 0.000850 & {$[42]$} \\
activated carbon & toluene & 0.209 & {$[19]$} \\
biochar & toluene & 0.178 & {$[19]$} \\
\hline
\end{tabular}

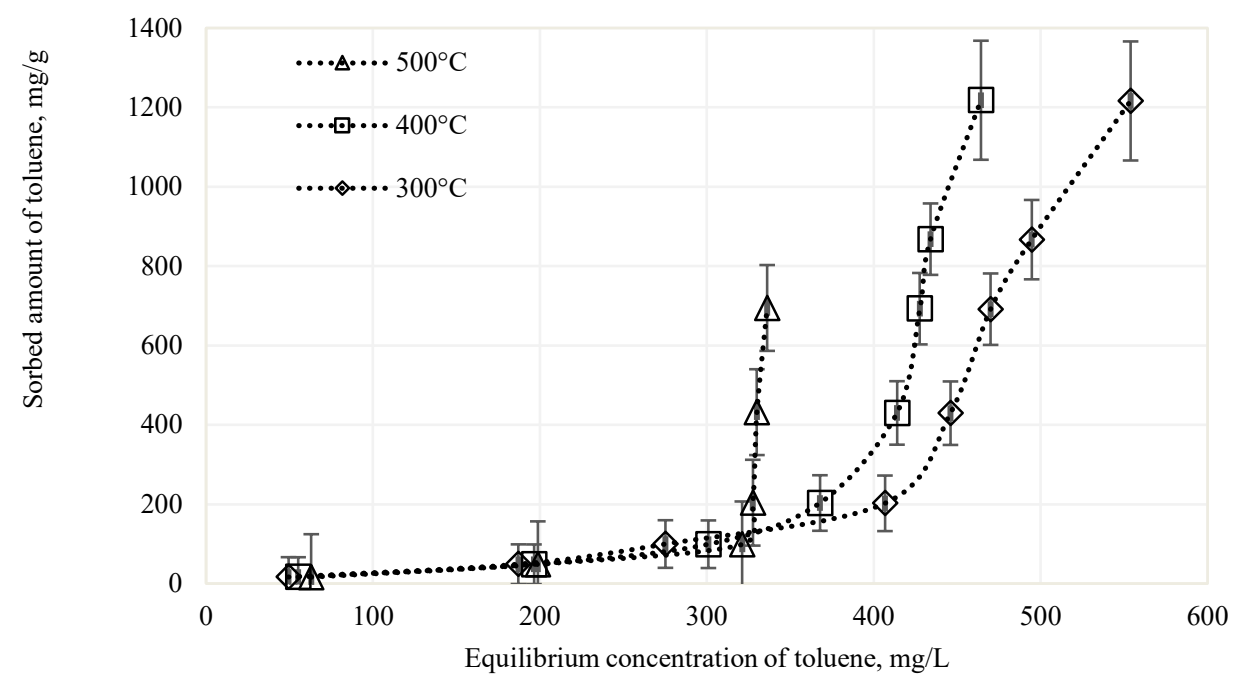

Fig. 5 Toluene sorption on biochar, sorption time $24 \mathrm{~h}$. 


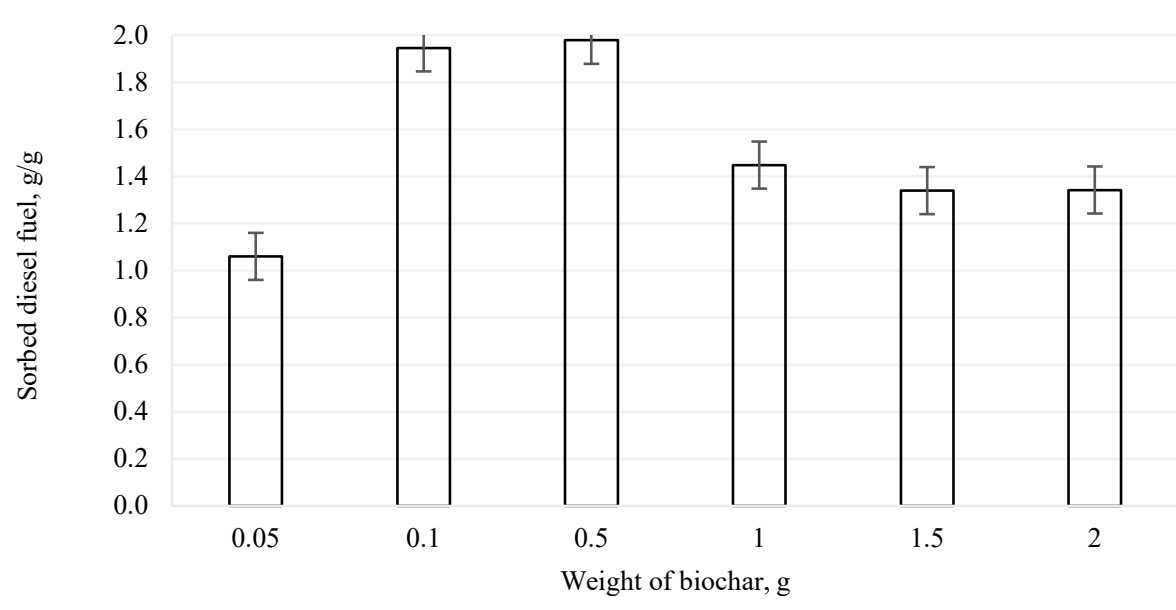

Fig. 6. The effect of sorbent dosage, sorption time $30 \mathrm{~min}$.

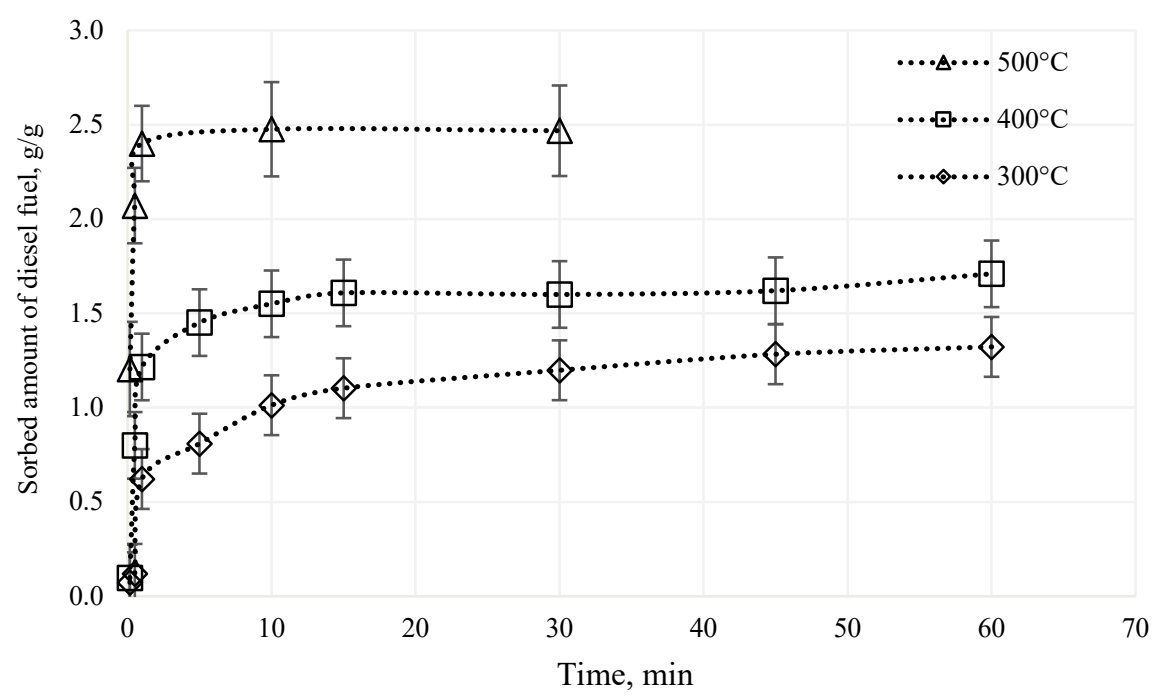

Fig. 7. Sorption kinetics of diesel fuel, sorbent dose $0.1 \mathrm{~g}$.

Kinetic models are often used to characterize sorption process. In order to explore mechanisms of sorption and potential rate controlling steps, for example chemical reaction processes and mass transport pseudo-first-order, pseudo-second order models have been applied to evaluate the experimental data. Appropriate sorption model was determined comparing the determination coefficients in the pseudo-first and pseudo-second-order equations. 
Pseudo first order reaction is expressed as:

where

$$
\ln \left(q_{e}-q_{t}\right)=\ln q_{e}-k_{1} t
$$

$\begin{array}{ll}q_{e} & \text { Diesel fuel sorbed at equilibrium, g/g; } \\ q_{t} & \text { Diesel fuel sorbed at time } t, \mathrm{~g} / \mathrm{g} ; \\ t & \text { Time, min; } \\ k_{1} & \text { Reaction rate constant, } 1 / \mathrm{min} .\end{array}$

Pseudo-first-order reaction rate constant can be determined from the slope of the $\ln \left(q_{e}-q_{t}\right)$ vs $t$ graph.

Pseudo second order reaction is expressed as:

$$
\frac{t}{q_{t}}=\frac{1}{k_{2} q_{e}^{2}}+\frac{1}{q_{e}},
$$

where $k_{2}$ - the reaction rate constant (g/g min); pseudo second order reaction rate constant $\left(k_{2}\right)$ can be determined from the slope of the $t / q_{t}$ vs $t$ graph [43].

The linear regression coefficient of determination $\left(R^{2}\right)$ and parameters of the pseudo-first and pseudo-second order reactions were calculated. Experimental data showed that the pseudo-second-order kinetic model could explain the sorption process of diesel fuel on biochar better than pseudo-first order model since the correlation coefficients $R^{2}$ were 0.997 , 0.998 and 0.999 for samples heated at $300{ }^{\circ} \mathrm{C}, 400{ }^{\circ} \mathrm{C}$ and $500{ }^{\circ} \mathrm{C}$ accordingly. The experimental values $q_{e}$ exp agreed well with the estimated $q_{e q}-1.32 \mathrm{~g} / \mathrm{g}, 1.70 \mathrm{~g} / \mathrm{g}$ and $2.48 \mathrm{~g} / \mathrm{g}$ (at corresponding temperatures $300{ }^{\circ} \mathrm{C}, 400{ }^{\circ} \mathrm{C}$ and $500{ }^{\circ} \mathrm{C}$ heated samples) values calculated from the pseudo-second order equation, and finally estimated reaction rate constant $k_{2}-$ $0.21 \mathrm{~g} / \mathrm{g}$ min for $300{ }^{\circ} \mathrm{C}$ heated sample, $k_{2}-0.47 \mathrm{~g} / \mathrm{g} \min \left(400{ }^{\circ} \mathrm{C}\right)$ and $k_{2}-4.76 \mathrm{~g} / \mathrm{g} \min$ $\left(500{ }^{\circ} \mathrm{C}\right)$.

\section{Conclusions}

Torrefaction/carbonization coupled with the subsequent washing of biochar is a method allowing to overcome absolute majority of the quality problems of waste derived fuels, including the most important one: high chlorine content. Solid fuel obtained as a result of such approach is clean and technically and environmentally safe. Technically it is possible to combine the washing of torrefied/carbonized waste derived fuels with the treatment of wastewaters that are polluted with oils or hydrocarbons. In spite the fact that optimal temperatures for upgrading waste derived fuels and to produce high quality sorbent does not coincide, torrefaction/carbonization of RDF produce biochars that are prospective as low-cost sorbents. RDF derived biochar exhibits good sorption properties towards toluene. The maximum diesel fuel sorption capacity of biochar is $2 \mathrm{~g} / \mathrm{g}$. The results of sorption kinetics of diesel fuel on biochar indicate that sorption capacity increases with increasing sorption time until it reaches the maximum of $2.55 \mathrm{~g} / \mathrm{g}$ after $24 \mathrm{~h}$. The theoretical equilibrium sorption capacities obtained by fitting the pseudo second-order kinetic were very close to the experimental values. 


\section{ACKNOWLEDGEMENTS}

The study was supported by University of Latvia grant Nr. AAp2016/B041//Zd2016/AZ03 within the "Climate change and sustainable use of natural resources" program and by the European Regional Development Fund within the project "Research of optical and energetic properties of mixed municipal solid waste material for its preparation for recovery" No.1.1.1.2/VIAA/1/16/221

\section{REFERENCES}

[1] Hoornweg D., Bhada-Tata P. What a waste: a global review of solid waste management. World Bank Washington DC., 2012:15:116.

[2] Tomić T., Schneider D. R. The role of energy from waste in circular economy and closing the loop conceptEnergy analysis approach. Renewable and Sustainable Energy Reviews 2018:98:268-287. https://doi.org/10.1016/j.rser.2018.09.029

[3] Jo M. H., Lee B. J., Lee J. Y. 2013. Effect of modified mechanical treatment facilities on SRF yield in Korea. Environmental and Climate technologies 2013:12(1):47-53. https://doi.org/10.2478/rtuect-2013-0016

[4] Arina, D., Orupe A. Characteristics of mechanically sorted municipal wastes and their suitability for production of refuse derived fuel. Environmental and Climate Technologies 2012:8(1):18-23. https://doi.org/10.2478/v10145-012-0003-0

[5] Yuan H., et al. Study of fuel properties of torrefied municipal solid waste. Energy and Fuels 2015:29(8):49764980. https://doi.org/10.1021/ef502277u

[6] Białowiec A., et al. The RDF/SRF torrefaction: An effect of temperature on characterization of the productCarbonized Refuse Derived Fuel. Waste Management 2017:70:91-100. https://doi.org /10.1016/j.wasman.2017.09.020

[7] Bar-Ziv E., et al. Properties of Torrefied US Waste Blends. Frontiers in Energy Research 2018:6:65. https://doi.org/10.3389/fenrg.2018.00065

[8] Nobre C., et al. Upgrading of refuse derived fuel through torrefaction and carbonization: Evaluation of RDF char fuel properties. Energy 2019:181:66-76. https://doi.org/10.1016/j.energy.2019.05.105

[9] Shankar Tumuluru J., et al. A review on biomass torrefaction process and product properties for energy applications. Industrial Biotechnology 2011:7(5):384-401. https://doi.org/10.1089/ind.2011.7.384

[10] Chen W. H., Peng J., Bi X. T. A state-of-the-art review of biomass torrefaction, densification and applications. Renewable and Sustainable Energy Reviews 2015:44:847-866. https://doi.org/10.1016/j.rser.2014.12.039

[11] Bach Q. V., Skreiberg Ø. Upgrading biomass fuels via wet torrefaction: A review and comparison with dry torrefaction. Renewable and Sustainable Energy Reviews 2016:54:665-677. https://doi.org/10.1016/j.rser.2015.10.014

[12] Silva C. M. S., et al. Biomass torrefaction for energy purposes-Definitions and an overview of challenges and opportunities in Brazil. Renewable and Sustainable Energy Reviews 2018:82(Part3):2426-2432. https://doi.org/10.1016/j.rser.2017.08.095

[13] Ma S., Lu J., Gao J. Study of the low temperature pyrolysis of PVC. Energy and Fuels 2002:16(2):338-342. https://doi.org/10.1021/ef0101053

[14] Saththasivam J., et al. A novel architecture for carbon nanotube membranes towards fast and efficient oil/water separation. Scientific Reports 2018:8(1):7418. https://doi.org/10.1038/s41598-018-25788-9

[15] Kuo C. H., Lee C. L. Treatment of oil/water emulsions using seawater-assisted microwave irradiation. Separation and Purification Technology 2010:74(3):288-293. https://doi.org/10.1016/j.seppur.2010.06.017

[16] Lü T., et al. Treatment of emulsified oil wastewaters by using chitosan grafted magnetic nanoparticles. Journal of Alloys and Compounds 2017:696:1205-1212. https://doi.org/10.1016/j.jallcom.2016.12.118

[17] Li J., et al. Blend-electrospun poly (vinylidene fluoride)/stearic acid membranes for efficient separation of waterin-oil emulsions. Colloids and Surfaces A: Physicochemical and Engineering Aspects 2018:538:494-499. https://doi.org/10.1016/j.colsurfa.2017.11.043

[18] Barroso-Solares S., et al. Enhanced oil removal from water in oil stable emulsions using electrospun nanocomposite fiber mats. RSC advances 2018:8(14):7641-7650. https://doi.org/10.1039/C7RA12646H

[19] Kiser B. Circular economy. Getting the circulation going. Nature 2016:531(7595):443-444. https://doi.org/10.1038/531443a

[20] Wahi R., et al. Oil removal from aqueous state by natural fibrous sorbent: an overview. Separation and Purification Technology 2013:113:51-63. https://doi.org/10.1016/j.seppur.2013.04.015

[21] Silvani L., et al. Characterizing biochar as alternative sorbent for oil spill remediation. Scientific Reports 2017:7:43912. https://doi.org/10.1038/srep43912

[22] ISO Standard № 18125: Solid Biofuels - Determination of Calorific Value. 2017. 
[23] ISO Standard № 16994: Solid biofuels - Determination of total content of sulphur and chlorine, 2011.

[24] ISO Standard № 16948: Solid Biofuels_-Determination of Total Content of Carbon, Hydrogen and Nitrogen, 2015.

[25] Agrawal R. K., A rapid technique for characterization and proximate analysis of refuse-derived fuels and its implications for thermal conversion. Waste Management and Research 1988:6(3):271-280. https://doi.org/10.1177/0734242X8800600143

[26] Naderi M. Surface Area: Brunauer-Emmett-Teller (BET). Progress in filtration and separation 2015:585-608.

[27] Zhang X., et al. Fabrication of Superhydrofobic kapok Fiber Using $\mathrm{CeO}_{2}$ and Octadecyltrimethoxysilane. Environmental Engineering Science 2017:35(7):1-7. https://doi.org/10.1089/ees.2017.0272

[28] Zhao Y., et al. A hierarchical and gradient structured supersorbent comprising three-dimensional interconnected porous fibers for efficient oil spillage cleanup. Journal of Materials Chemistry A 2016:4:9635-9643. https://doi.org/10.1039/C6TA02979E

[29] Peng L., et al. Electrospun PS/PAN fibres with improved mechanical property for removal of oil from water. Marine Pollution Bulletin 2015:93:75-80. https://doi.org/10.1016/j.marpolbul.2015.02.012

[30] Buekens A., Cen K. Waste incineration, PVC, and dioxins. Journal of Material Cycles and Waste Management 2011:13(3):190-197. https://doi.org/10.1007/s10163-011-0018-9

[31] Rademakers P., Hesseling W., Van de Wetering, J. Review on corrosion in waste incinerators, and possible effect of bromine. TNO Industrial Technology 2002:18-25.

[32] Lopes C. B., et al. Cork stoppers as an effective sorbent for water treatment: the removal of mercury at environmentally relevant concentrations and conditions. Environmental Science and Pollution Research 2014:21:2108-2121. https://doi.org/10.1007/s11356-013-2104-0

[33] Brunauer S., et al. On a theory of the van der Waals adsorption of gases. Journal of the American Chemical Society 1940:62(7):1723-1732. https://doi.org/10.1021/ja01864a025

[34] Giles C. H., et al. Studies in Adsorption. Part XI. A System of Classification of Solution Adsorption Isotherms, and its Use in Diagnosis of Adsorption Mechanisms and in Measurement of Specific Surface Areas of Solids. Journal of Chemical Society 1960:3973-3993. https://doi.org/10.1039/JR9600003973

[35] Peng D., et al. Sorption of crude oil by enzyme -modified corn stalk vs. chemically treated corn stalk. Journal of Molecular Liquids 2018:255:324-332. https://doi.org/10.1016/j.molliq.2018.01.178

[36] Paulauskiene T., et al. The use of natural sorbents for spilled crude oil and diesel cleanup from the water surface. Water Air and Soil Pollution 2014:225:1959. https://doi.org/10.1007/s11270-014-1959-0

[37] Hai J., et al. Removal of oil from water surface by novel composite NSM-g-P (MMA-co-BA) Super Oil absorption Resin. Polymer Composites 2016:39(4):1051-1063. https://doi.org/10.1002/pc.24032

[38] Abdelwahab O. Assessment of raw luffa as a natural hollow oleophilic fibrous sorbent for oil spill cleanup. Alexandria Engineering Journal 2014:53:213-218. https://doi.org/10.1016/j.aej.2013.11.001

[39] Klavins M., Porshnov D. Approaches for peat modification to improve oil sorption capacity. Proceeding of Recent Researches in Geography, Geology, Energy, Environment and Biomedicine 2011:48-53.

[40] Klavins M., Porshnov D. Development of a new peat-based oil sorbent using peat pyrolysis. Environmental technology 2013:34(12):1577-1582. https://doi.org/10.1080/09593330.2012.758668

[41] Sidik S. M., et al. Modified oil palm leaves adsorbent with enhanced hydrophobicity for crude oil removal. Chemical Engineering Journal 2012:203:9-18. https://doi.org/10.1016/j.cej.2012.06.132

[42] Jayawardhana Y. et al. Sorptive removal of toluene and $\mathrm{m}$-xylene by municipal solid waste biochar: Simultaneous municipal solid waste management and remediation of volatile organic compounds. Journal of Environmental Management 2019:238:323-330. https://doi.org/10.1016/j.jenvman.2019.02.097

[43] Krivinos O. I., et al. Sapropels as a source of sorbents for cleaning the surface of water areas from petroleum products. AIP Conference Proceedings 2019:2143:020051 https://doi.org/10.1063/1.5122950 